\title{
Short-term impact of bait digging on intertidal macrofauna of tidal mudflats around the Kneiss Islands (Gulf of Gabès, Tunisia)
}

\author{
Nawfel MosBaHI ${ }^{1, a}$, Jean-Philippe PEZY ${ }^{2}$, Jean-Claude DAUVIN ${ }^{2}$ and Lassad NEIFAR ${ }^{1}$ \\ ${ }^{1}$ Laboratoire de Biodiversité et Ecosystèmes Aquatiques, Faculté des Sciences de Sfax, Université de Sfax, BP 1171, 3038 Sfax, Tunisie \\ 2 UNICAEN, CNRS, UMR 6143 M2C, Laboratoire Morphodynamique Continentale et Côtière, 24 rue des Tilleuls, 14000 Caen, France
}

Received 26 August 2015; Accepted 18 January 2016

\begin{abstract}
In the Gulf of Gabès (South-eastern Tunisia), polychaete bait digging is widely practiced for recreational and commercial fishing and is an economically significant activity. The present study aims to assess the short-term effects of intertidal bait digging on macrobenthic communities from the Kneiss Islands. Following a protocol with a control station (not impacted) and three impacted stations for polychaete collection, the study was conducted during March and April 2015 at spring tides. After digging, immediate significant decreases were observed in the abundance of total macrofauna as well in numerous families of polychaetes. Control of this activity should be proposed for the future to protect the biodiversity of this intertidal area of high heritage interest.
\end{abstract}

Keywords: Bait harvesting / Macrofauna diversity / Gulf of Gabès / Polychaetes

\section{Introduction}

Coastal areas in general are very productive and ecologically important. But they are also extremely sensitive (Afli et al. 2009), because they are exposed to several anthropogenic disturbances which can affect organisms at several biological scales (Halpern et al. 2008). In fact, coastal marine benthic communities are threatened by human activities, and the present rate of habitat degradation is alarming (Gray 1997; Snelgrove et al. 1997). Indeed, effective environmental management involves the assessment of resource exploitation in relation to environmental degradation (Ellis et al. 2000).

The Kneiss Islands, situated in the Gulf of Gabès, located in the southern Tunisia, represent the most important coastal wetlands in Mediterranean Sea, and make up a very important intertidal area exploited for clam harvesting and the collection of polychaete bait by the local population (Abdennadher et al. 2011; Mosbahi et al. (submitted)). Three polychaete families (Nereididae, Eunicidae and Arenicolidae) are commercially collected from natural populations, to be used as baits, by semi-professional bait harvesters, either by hand or with fishing gear, using rakes or stainless steel spatula for digging into the sand and tidal mudflats (El Barhoumi et al. 2013). Due to the biodiversity of its intertidal zone (Mosbahi et al. 2015), this gulf has long been recognized as one of the most important wintering areas for Palearctic waterbirds migrating via the Mediterranean (Van Dijk et al. 1986; Isenmann et al. 2005; Hamdi et al. 2008; Hamza et al. 2015).

\footnotetext{
a Corresponding author: nawfelmosbahi@hotmail.fr
}

Bait digging from intertidal and estuarine habitats is practiced worldwide, and supports the subsistence of many small fishing communities (Watson et al. 2007; Carvalho et al. 2013a, 2013b; http://www.ukmarinesac.org.uk/activities/ bait-collection/bc18.htm). The very large intertidal sand and mudflat zone of Kneiss Islands is exploited for bait harvesting, mainly targeted on the species i.e. Arenicola marina (Linnaeus 1758), Hediste diversicolor (Müller 1776), Marphysa sanguinea (Montagu 1815) and Perinereis cultrifera (Grube 1840). Traditionally, bait digging in intertidal areas has been undertaken by hand or using rudimentary fishing gear for overturn the sediments. However, in some countries, traditional collection methods have been superseded by mechanized methods (Ferns et al. 2000). Still though, tidal flats used by waterbirds during the foraging activity and nesting period are also exploited by humans, especially for traditional clam harvesting.

The aim of this study is to assess, for the first time in Tunisia, the immediate impact of polychaete digging on the intertidal macrozoobenthic diversity (Number of taxa / Abundance) during the period March-April 2015.

\section{Materials and methods}

\subsection{Sampling site}

The intertidal area of the Kneiss Islands is located in the north-western part of the Gulf of Gabès (south-eastern 


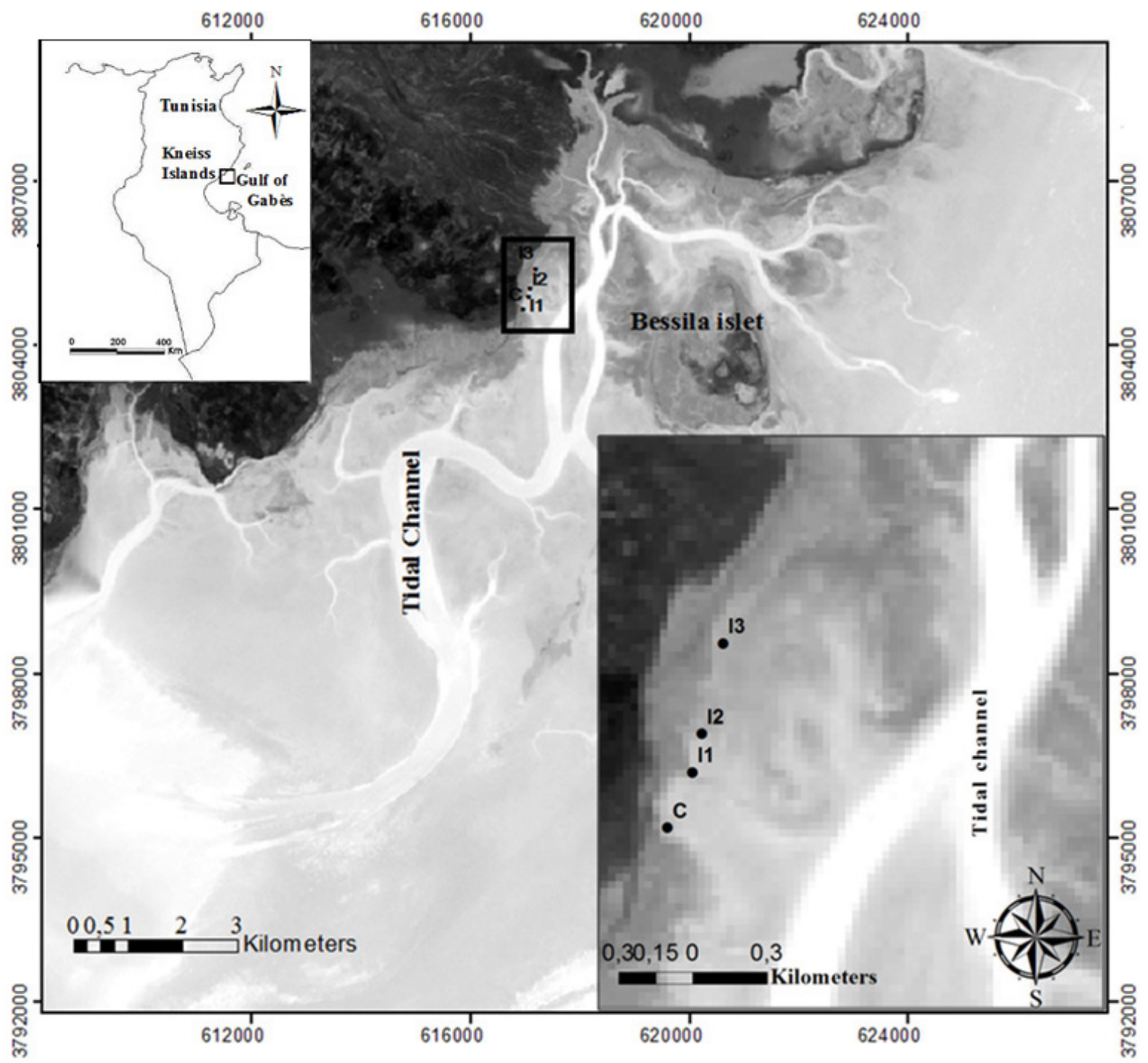

Fig. 1. Location of all sampling stations (I1, I2, I3 and C) in the intertidal zone of the Kneiss Islands (Gulf of Gabès, Tunisia) (Coordinates in WGS84).

Tunisia) between latitudes $34^{\circ} 10^{\prime}-34^{\circ} 30^{\prime} \mathrm{N}$ and longitudes $10^{\circ}-10^{\circ} 30^{\prime} \mathrm{E}$ (Fig. 1). The tides are semidiurnal, attaining a range of $2.3 \mathrm{~m}$ during spring tides (Seurat 1924; Sammari et al. 2006). The mudflats of the Kneiss Islands are composed by muddy to sandy muddy sediments (Bali and Gueddari 2011), colonized by the seagrass Zostera noltei (Hornemann 1832), protected species listed in the IUCN Red List of threatened species in Mediterranean Sea, as characterizing a diversified habitat requiring monitoring and protection. Due to their biodiversity, the Kneiss Islands were declared as a nature reserve in 1993, then as a "Specially Protected Area of Mediterranean Importanc" (SPAM) in 2001, an "Important Bird Area" (IBA) in 2003 and a "RAMSAR site" in 2007.

\subsection{Macrofauna sampling}

Benthic macrofauna sampling was performed between March and April 2015, by collecting the top most $0.3 \mathrm{~m}$ of the sediment with a $0.0225 \mathrm{~m}^{2}$ corer (core diameter of $0.15 \mathrm{~m}$ ) with eight replicates per station. The sampling was carried out at three stations (i.e., I1, I2 and I3) in zones where the fishers collect four polychaete target species, i.e. A. marina, $H$. diversicolor, $M$. sanguinea and $P$. cultrifera, as well as at a control station (C) in an area where digging polychaetes is normally forbidden (Not impacted) (Fig. 1). Each station situated on a Zostera noltei meadow was located with a GPS and was visited during two sampling campaigns. The first campaign was on 6 March, coinciding with the beginning of the annual bait collection period denoted here as B (for before). The second campaign took place on 4 April (after a month of polychaete collection) denoted here as A (one month after bait digging started).

Samples were sieved through a 1-mm mesh, fixed with buffered formalin $10 \%$ and stained with Rose Bengal to facilitate the sorting. In the laboratory, the species were sorted and identified to species level (whenever possible) and preserved in $70 \%$ ethanol. 
Table 1. Main characteristics of stations used in sampling campaign on 6 March 2015.

\begin{tabular}{cccccccccccc}
\hline \multirow{2}{*}{ Stations } & \multicolumn{9}{c}{ Coordinates } & \multicolumn{9}{c}{ Grain size fraction $(\%)$} & \multirow{2}{*}{ Sediment type } & Organic \\
& \cline { 2 - 10 } & Longitude E & Latitude N & $>2000$ & $<2000$ & $<1000$ & $<500$ & $<250$ & $<125$ & $<63$ & \\
\hline I1 & 32.617067 & 38.04883 & 1.30 & 4.80 & 6.85 & 18.35 & 34.17 & 29.58 & 5.22 & Fine Sand & 2.54 \\
I2 & 32.617105 & 38.05038 & 0.30 & 1.80 & 4.61 & 13.35 & 59.20 & 22.13 & 8.57 & Fine Sand & 2.42 \\
I3 & 32.617192 & 38.05405 & 0.50 & 0.35 & 0.78 & 2.33 & 71.65 & 16.05 & 8.34 & Fine Sand & 2.18 \\
C & 32.616966 & 38.04658 & 0.02 & 0.02 & 0.05 & 4.84 & 78.17 & 12.97 & 3.93 & Fine Sand & 2.25 \\
\hline
\end{tabular}

\subsection{Sediment Analysis}

For grain-size analysis, sediment from each sample was homogenized and wet-sieved through a $63 \mu \mathrm{m}$ mesh to separate mud (including silt and clay) and sandy fractions (retained in the sieve). After being oven-dried to constant weight at $60{ }^{\circ} \mathrm{C}$, sandy fractions were separated using a mechanical shaker (column of six sieves of mesh sizes 2, 1, 0.5, 0.25, 0.125 and $0.063 \mathrm{~mm}$ ) for $10 \mathrm{~min}$. All fractions (including the fines $<63 \mu \mathrm{m}$ ) were then weighed and to determine the percentages. For the organic matter (OM) content, sediment samples were dried at $80^{\circ} \mathrm{C}$ to constant weight and ground to a fine powder. OM content was determined in the powder samples by "loss on ignition" at $450{ }^{\circ} \mathrm{C}$ for $4 \mathrm{~h}$ (Table 1 ).

\subsection{Statistical analyses}

Multivariate and univariate techniques are utilized here to test hypotheses about changes in the structure and composition of macrobenthic assemblages due to polychaete digging. The taxonomic richness (number of taxa) and abundance are considered per replicate.

For the biological parameters, a Shapiro-Wilk normality test and a Bartlett's test for homogeneity of variance are performed prior to each ANOVA to check whether the assumptions of ANOVA are met and if data transformation is necessary. Then, ANOVAs are performed to assess the effect of bait digging on benthic abundance and taxonomic richness for both campaigns. A Tukey Honestly Significant Difference test is employed to determine differences before and after raking as well as between the three sediment types.

Then, a square root transformation is applied to the abundance matrix (data for each station are pooled prior to undertaking further analyses), before calculating the BrayCurtis similarities using the statistical package PRIMER ${ }^{\circledR}$. 6.0 (Clarke and Gorley 2006). A dendrogram is created, with group averages expressed in the cluster mode. Then, a nonparametric multi-dimensional scaling (MDS) ordination, using the Bray-Curtis similarity measure, is applied to the abundance matrix (after square root transformation), with the objective of examining the structure of the intertidal endofauna. The SIMilarity PERcentages (SIMPER) routine is applied to establish which species contribute most to the observed differences in the data. ANOSIM (ANalysis of SIMilarities) (Clarke 1993) is also carried out to test for significant differences in intertidal endofauna composition in response to raking (one-way analysis).

\section{Results}

Bait digging is a recent activity on the intertidal zone around the Kneiss Islands. However, with the aim of preserving the stock during the winter reproductive period, but rather in relation with the high productive period of clam Ruditapes decussatus (Linnaeus 1758), which is exploited mainly by the same fishers (Mosbahi et al. (submitted)); the fishing activity is relatively less intense from the beginning of December to the end of February (three months), and extends with full intensity from the 1st March to the 30th November. Around the Kneiss Islands, nearly 100 fishermen exercise this activity every day during the harvest period (270 days). Bait harvesters can dig about 100-150 worms/day for a fresh weight estimated at $0.3 \mathrm{~kg}$; they sell their harvest directly after fishing to a wholesaler who sells the bait to Tunisian fishermen and for the export market. Thus, we estimate that about 8 tonnes are collected per year in the target zones of the Kneiss Islands.

\subsection{Main characteristics of sediment and macrofauna}

Sampled stations are colonized by Zostera noltei and the grain-size analyses show that the sediments at the four stations are mainly composed of fine sand. The organic matter content is closely similar for all stations (between 2.0 and $2.5 \%$ ) (Table 1).

A total of 63 species were collected belonging to six zoological groups unequally distributed among the sampling stations. Annelid polychaetes are dominant $(37 \%$ of total number of species), followed by crustaceans (27\%), mainly amphipods, isopods, decapods and mysids, along with molluscs (27\%), mainly bivalves and gastropods. The other three phyla (echinoderms, cnidarians, and tunicates) account for only $9 \%$ of the total number of species.

\subsection{Short-term impact of bait digging on intertidal macrofauna}

Before the polychaete bait collection period, the faunal composition was predominately composed of polychaetes (2033 ind. in the 32 replicates of $0.0225 \mathrm{~m}^{2}$ ), with abundant representatives of the Nereididae, Arenicolidae and Cirratulidae, and also by molluscs (1614 ind.), dominated by Scrobiculariidae, Cerithiidae, Cardiidae and Potamididae.

After bait digging, the number of taxa (species richness) and abundance in the $0.0225 \mathrm{~m}^{2}$ are decrease, for the abundance that is almost $-50 \%$ (Tables 2 and 3), as well as the disappearance of some polychaetes, such as Amphitritides gracilis (Grube 1860), Heteromastus filiformis (Claparède 1864) 
Table 2. Number of species (richness) and total benthic abundance for each station, Before and After bait digging. Mean values with the same superscript are not significantly different (Tukey's HSD test; $p>0.05$ ) (I1, I2, and I3: Impacted stations; C: Control station).

\begin{tabular}{ccccc}
\hline \multirow{2}{*}{ Stations } & \multicolumn{2}{c}{ Taxonomic richness } & \multicolumn{2}{c}{ Total benthic abundance } \\
\cline { 2 - 5 } & Before & After & Before & After \\
\hline I1 & $35.5 \pm 4.6^{\mathrm{a}}$ & $20.5 \pm 4.0^{\mathrm{b}}$ & $168.4 \pm 24.5^{\mathrm{c}}$ & $51.4 \pm 8.7^{\mathrm{d}}$ \\
I2 & $31.7 \pm 4.4^{\mathrm{a}}$ & $20.6 \pm 3.0^{\mathrm{b}}$ & $132.6 \pm 22.9^{\mathrm{c}}$ & $48.7 \pm 5.4^{\mathrm{d}}$ \\
I3 & $32.6 \pm 4.0^{\mathrm{a}}$ & $20.2 \pm 1.7^{\mathrm{b}}$ & $156.0 \pm 21.1^{\mathrm{c}}$ & $60.9 \pm 9.5^{\mathrm{d}}$ \\
C & $38.1 \pm 2.2^{\mathrm{a}}$ & $36.5 \pm 3.0^{\mathrm{a}}$ & $169.5 \pm 16.4^{\mathrm{c}}$ & $137.8 \pm 7.9^{\mathrm{c}}$ \\
\hline
\end{tabular}

Table 3. Density of individuals recorded at all the stations sampled during the two campaigns (March and April 2015).

\begin{tabular}{|c|c|c|c|c|}
\hline \multirow{3}{*}{ Species } & \multicolumn{4}{|c|}{ Total number of individuals (on area of $0.0225 \mathrm{~m}^{2}$ ) } \\
\hline & \multicolumn{2}{|c|}{ Impacted stations (I1, I2, I3) } & \multicolumn{2}{|c|}{ Non-impacted station $(\mathrm{C})$} \\
\hline & Before & After & Before & After \\
\hline Actinia equina (Linnaeus 1758) & 5 & 7 & 2 & 3 \\
\hline Alpheus inopinatus (Holthuis and Gottlieb 1958) & 14 & 7 & 16 & 9 \\
\hline Amphipholis squamata (Delle Chiaje 1828) & 11 & 9 & 7 & 9 \\
\hline Amphitritides gracilis (Grube 1860) & 20 & 0 & 9 & 16 \\
\hline Anthura gracilis (Montagu 1808) & 49 & 11 & 13 & 21 \\
\hline Aoridae & 27 & 10 & 14 & 21 \\
\hline Arenicola marina (Linnaeus 1758) & 131 & 45 & 61 & 1 \\
\hline Asterina pancerii (Gasco 1870) & 10 & 6 & 3 & 2 \\
\hline Bulla striata Bruguière 1792 & 12 & 3 & 4 & 4 \\
\hline Carcinus aestuarii Nardo 1847 & 7 & 7 & 5 & 3 \\
\hline Cerastoderma glaucum (Bruguière 1789) & 115 & 26 & 41 & 13 \\
\hline Cerithium scabridum Philippi 1848 & 333 & 100 & 122 & 55 \\
\hline Cerithium vulgatum Bruguière 1792 & 8 & 18 & 0 & 13 \\
\hline Chiton olivaceus Spengler 1797 & 46 & 36 & 15 & 17 \\
\hline Cirratulus cirratus (Müller 1776) & 232 & 94 & 90 & 82 \\
\hline Cirriformia tentaculata (Montagu 1808) & 32 & 17 & 8 & 6 \\
\hline Conus ventricosus Hwass in Bruguière 1792 & 2 & 4 & 2 & 4 \\
\hline Cyathura carinata (Krøyer 1847) & 49 & 12 & 22 & 22 \\
\hline Cyclope neritea (Linnaeus 1758) & 31 & 6 & 9 & 6 \\
\hline Cymadusa filosa Savigny 1816 & 21 & 9 & 25 & 12 \\
\hline Dexamine spiniventris (Costa 1853) & 97 & 25 & 33 & 37 \\
\hline Dexamine spinosa (Montagu 1813) & 27 & 12 & 23 & 17 \\
\hline Euclymene oerstedii (Claparède 1863) & 219 & 116 & 94 & 85 \\
\hline Eulymene lumbricoides (Quatrefages 1866) & 41 & 10 & 16 & 18 \\
\hline Gammarus insensibilis Stock 1966 & 40 & 14 & 26 & 29 \\
\hline Hediste diversicolor (O.F. Müller 1776) & 182 & 45 & 88 & 29 \\
\hline Heteromastus filiformis (Claparède 1864) & 39 & 0 & 6 & 9 \\
\hline Hexaplex trunculus (Linnaeus 1758) & 14 & 2 & 3 & 20 \\
\hline Holothuria & 5 & 0 & 3 & 5 \\
\hline Idotea balthica (Pallas 1772) & 64 & 31 & 24 & 27 \\
\hline Idotea granulosa Rathke 1843 & 11 & 2 & 6 & 15 \\
\hline Leiochone leiopygos (Grube 1860) & 17 & 8 & 6 & 7 \\
\hline Loripes lucinalis (Lamarck 1818) & 42 & 22 & 8 & 17 \\
\hline Marphysa bellii (Audouin \& Milne Edwards 1833) & 22 & 18 & 8 & 16 \\
\hline Marphysa sanguinea (Montagu 1815) & 20 & 11 & 6 & 2 \\
\hline Melinna palmata Grube 1870 & 50 & 37 & 43 & 44 \\
\hline Melita palmata (Montagu 1804) & 80 & 24 & 46 & 45 \\
\hline Microdeutopus gryllotalpa Costa 1853 & 75 & 20 & 42 & 33 \\
\hline Monocorophium insidiosum (Crawford 1937) & 200 & 26 & 83 & 28 \\
\hline Mysidae & 91 & 12 & 34 & 9 \\
\hline Nassarius corniculum (Olivi 1792) & 51 & 9 & 7 & 6 \\
\hline
\end{tabular}


Table 3. Continued.

\begin{tabular}{lcccc}
\hline \multirow{2}{*}{ Species } & \multicolumn{3}{c}{ Total number of individuals (on area of 0.0225 $\mathrm{m}^{2}$ ) } \\
\cline { 2 - 5 } & Impacted stations (I1, I2, I3) & Non-impacted station (C) \\
\cline { 2 - 5 } & Before & After & Before & After \\
\hline Nephtys hombergii Savigny in Lamarck 1818 & 14 & 10 & 6 & 8 \\
Nereis caudata (Delle Chiaje 1822) & 23 & 3 & 4 & 9 \\
Nereis rava Ehlers 1864 & 6 & 4 & 5 & 2 \\
Neverita josephinia Risso 1826 & 17 & 4 & 0 & 9 \\
Nicomache sp. & 7 & 4 & 3 & 7 \\
Ophiactis virens (M. Sars 1857) & 4 & 1 & 2 & 3 \\
Orbinia cuvierii (Audouin \& Milne Edwards 1833$)$ & 12 & 3 & 2 & 3 \\
Ostreola stentina (Payraudeau 1826) & 8 & 4 & 1 & 7 \\
Perinereis cultifera (Grube 1840) & 223 & 62 & 85 & 40 \\
Pinctada radiata (Leach 1814) & 45 & 14 & 16 & 14 \\
Platynereis dumerilii (Audouin \& Milne Edwards 1834$)$ & 25 & 8 & 27 & 21 \\
Polydora ciliate (Johnston 1838) & 22 & 18 & 10 & 12 \\
Potamides conicus (Blainville 1829) & 194 & 64 & 21 & 21 \\
Pseudoprotella phasma (Montagu 1804) & 11 & 6 & 1 & 12 \\
Ruditapes decussatus (Linnaeus 1758) & 51 & 14 & 14 & 20 \\
Sabella pavonina Saint-joseph 1894 & 45 & 0 & 10 & 10 \\
Scoloplos armiger (Müller 1776) & 35 & 26 & 11 & 12 \\
Scrobicularia plana (da Costa 1778) & 306 & 155 & 51 & 55 \\
Serpula vermicularis Linnaeus 1767 & 17 & 4 & 1 & 5 \\
Solemya togata (Poli 1791) & 19 & 0 & 6 & 0 \\
Sphaeroma serratum (Fabricius 1787) & 17 & 3 & 5 & 14 \\
Tunicata sp. & 13 & 10 & 2 & 1 \\
\hline
\end{tabular}

and Sabella pavonina (Saint-Joseph 1894), along with the Holothuria (Table 3).

Table 2 reports the total number of individuals sampled in each replicate and at each station (mean \pm SD) for both dates.

Firstly, all control station abundances are higher before and after one month of harvesting bait compared with the other stations (i.e. $169.5 \pm 16.4$ and $137.8 \pm 7.9$ recorded individuals per $0.0225 \mathrm{~m}^{2}$ ). The species richness and abundances at the three impacted stations are higher before (B) versus after (A) bait digging. Thus, it appears that bait digging causes a decrease in the number of species and total benthic abundance in the intertidal zone of the Kneiss Islands (Table 3).

Before bait digging, no significant difference is observed between the four stations for the taxonomic richness (ANOVA, $F_{3.28}=1.982 ; p=0.472$ ) or for the abundance of the macrofauna (ANOVA, $F_{3.28}=2.731 ; p=0.177$ ) (Table 2). A strong effect on benthic abundance and taxonomic richness is observed one month after bait digging: the taxonomic richness decreases significantly at the three impacted station (ANOVA, $\left.F_{7.56}=85.75 ; p<2 \mathrm{e}^{-16}\right)$, and a similar decrease is observed in total benthic abundance (ANOVA, $F_{7.56}=106.8 ; p<2 \mathrm{e}^{-16}$ ). After bait digging, no decrease of taxonomic richness and benthic abundance is observed at the Control station, showing that the differences at the impacted stations (I1, I2 and I3) are due exclusively to bait digging (Table 2).

The dendrogram (Fig. 2A) shows the separation of the eight situations into two main groups: the first group (GI) corresponds to the four stations sampled before bait collection plus the control one month after the beginning of the bait digging period, and the second group (GII) gathers together the three stations impacted by bait digging. The MDS ordination (Fig. 2B) showed a remarkable spatial separation between Group I (five situations) and Group II (three impacted stations). SIMPER illustrates the biological significance of the clustering before and after bait digging (Fig. 2) by displaying the group similarity and identifying the species contributing most to the dissimilarity between groups. The main species contributing to the dissimilarity was given in Table 4 . The ANOSIM shows that the two groups are statistically highly separated $(r=1, p=0.018)$ (Table 4).

\section{Discussion}

The objective of this study is to assess the immediate impact of polychaetes bait collection on the surrounding intertidal benthic macrofauna from the tidal flats of the Kneiss Islands.

Bait digging for recreational and commercial fishing is widely practiced in many parts of the world and is an economically significant activity. Since polychaetes form part of the diets of several demersal species, they are commonly used as fresh bait by sports and professional fishermen (Olive 1993; Cunha et al. 2005).

Two human activities have become well developed over the last decades on the intertidal zone around the Kneiss Islands, clam harvesting (Mosbahi et al. (submitted)) and bait digging. These human activities have many effects on the intertidal macrobenthic fauna, which is an essential element in the food 


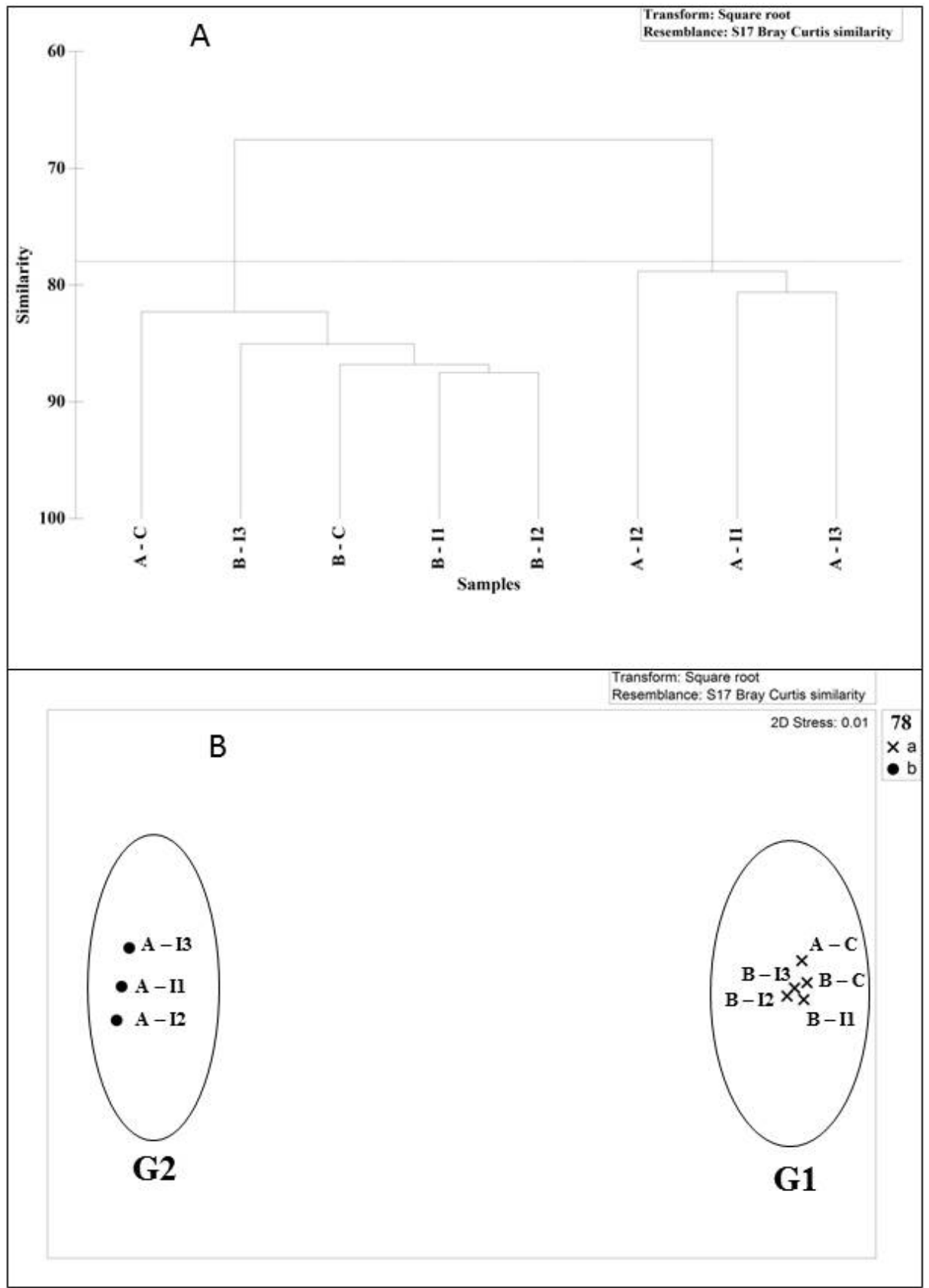

Fig. 2. (A) dendrogram and (B) two-dimensional MDS ordination/clustering of community data into two groups (G1 and G2) for each impacted station (I1, I2 and I3) and Control station (C). Sample prefixes B: Before digging; A: After digging.

Table 4. MDS formed groups, with indication each group similarities (\%) and the most representative species (\%) contributing for the similarity within the group, determined with SIMPER analysis.

\begin{tabular}{lll}
\hline Group & \multicolumn{1}{c}{ I } & \multicolumn{1}{c}{ II } \\
\hline Group mean similarity & \multicolumn{1}{c}{84.54} & \multicolumn{1}{c}{79.43} \\
Main species (after each & Dexamine spiniventris -29.75 & Potamides conicus -28.93 \\
species the \% of & Monocorophium insidiosum -27.07 & Perinereis cultrifera -25.05 \\
contribution for the & Hediste diversicolor -23.67 & Cerithium scabridum -21.01 \\
similarity within the & Scrobicularia plana -20.27 & Cirratulus cirratus -16.61 \\
group) & Perinereis cultrifera -16.60 & Euclymene oerstedi -11.78 \\
& Cerithium scabridum -12.74 & Scrobicularia plana -6.01 \\
& Cirratulus cirratus -8.67 & \\
& Euclymene oerstedi -4.33 & \\
\hline
\end{tabular}


chain in marine ecosystems (Turpie et al. 2002; Gray and Elliot 2009; Henninger and Froneman 2011).

The fauna is mainly composed of polychaetes (number of taxa and abundance of individuals), the more abundant families being the Nereididae, Arenicolidae (fishing target species) and the Cirratulidae. Bait digging does not lead to marked sediment changes (percentage of grain-size classes and organic matter content remain constant one month after the beginning of bait digging); nevertheless, the number of taxa and abundance of individuals are affected. For both periods, the abundances estimated at the control stations are significantly higher than those estimated at the three stations before and after bait collection, with some polychaetes, Heteromastus filiformis (Capitellidae), Amphitritides gracilis (Terebellidae) and Sabella pavonina (Sabellidae) disappearing after one month of bait digging. This indicates that the intertidal macrozoobenthic biodiversity at the impacted stations is affected by the type of destructive gear or possibly by trampling (Rossi et al. 2007; Navon and Dauvin 2013).

The decrease in abundance and diversity of intertidal macrofauna after bait digging has been commonly observed, and is thought to be due to direct and indirect mortality (destruction of tubes, exposure to predators and habitat destruction including seagrass reduction) (Brown and Wilson 1997; Cowie et al. 2000; Munari et al. 2006; Carvalho et al. 2013a, 2013b). Usually, the abundance of tubicolous polychaetes decreases after impact, under the effects of fishing gear and human trampling which eliminate the most vulnerable organisms and modify the habitat structure. Therefore, these organisms respond negatively to human activities (invertebrate harvesting or bottom trawling), since they are highly vulnerable and considerably reduced in abundance, and sometimes entirely eliminated by fishing activities, being extremely fragile and particularly susceptible to damage (Kaiser and Spencer 1994; Wassenberg et al. 2002; De Juan et al. 2007).

Macrobenthic assemblages may respond differently to the same intensity, frequency or nature of disturbance, depending on their biological traits; organisms resistant to disturbance can be considered as better indicators than opportunistic species, since the former tend to adapt easily and respond weakly to disturbance (Carvalho et al. 2013a, 2013b; Frid 2003; De Juan et al. 2007). The existence of less diverse assemblages with a consequent reduction of ecological functions may magnify the effects of bait digging, as mortality due to fishing has been shown to be related to animal size, animal type, position in sediment, the existence of external protective structures and body design (Jennings et al. 2001; De Juan et al. 2007).

This preliminary study constitutes the first ecological impact of bait digging on the intertidal macrobenthic communities in the foreshore of the Gulf of Gabès; it can be considered as a baseline for further studies on the impact of traditional human activities on the benthic communities from the Gulf of Gabès. For the moment, there is no data on the impact of this activity on the target species stocks.

Acknowledgements. The authors thank M. Carpenter for the English revision, as well as the fishers of the Kneiss Islands for their help during the sampling, two anonymous referees and the Editor-in-Chief of Aquatic Living Resources for their very useful comments and suggestions.

\section{References}

Abdennadher A., Ramirez F., Romdhane M.S., Ruiz L.J., Sanpera C., 2010, Biomonitoring of coastal areas in Tunisia: Stable isotope and trace element analysis in the Yellow-legged Gull. Mar. Poll. Bull. 60, 440-447.

Afli A., Boufahja F., Sadraoui S., Ben Mustapha K., Aissa P., Mrabet R., 2009, Functional organization of the benthic macrofauna in the Bizerte lagoon (SW Mediterranean Sea), semienclosed area subject to strong environmental/anthropogenic variations. Cah. Biol. Mar. 50, 105-117.

Bali M., Gueddari M., 2011, Les chenaux de marée autour des îles de Kneiss, Tunisie: sédimentologie et évolution. Hyd. Sci. J. 56, 498-506.

Brown B., Wilson W.H., 1997, The role of commercial digging of mudflats as an agent for change of infaunal intertidal populations. J. Exp. Mar. Bio. Ecol. 218, 49-61.

Carvalho A., Vaz A., Sérgio T., Santos P.T., 2013a, Sustainability of bait fishing harvesting in estuarine ecosystems - Case study in the Local Natural Reserve of Douro Estuary, Portugal. J. Int. Coast. Zo. Man. 13, 157-168.

Carvalho S., Constantino R., Cerqueira M., Pereira F., Subida M.D., Drake P., Gasper M.B., 2013b, Short-term impact of bait digging on intertidal macrozoobenthic assemblages of two Iberian Atlantic systems. Estuar. Coast. Shelf. Sci. 132, 65-76.

Clarke K.R., 1993, Non parametric multivariate analyses of changes in community structure. Aust. J. Ecol. 18, 117-143.

Clarke K.R., Gorley R.N., 2006, PRIMER V6: User Manual/Tutorial. PRIMER-E, Plymouth.

Cowie P.R., Widdicombe S., Austen M.C., 2000, Effects of physical disturbance on an estuarine intertidal community: field and mesocosm results compared. Mar. Biol. 136, 485-495.

Cunha T., Hall A., Queiroga H., 2005, Estimation of the Diopatra neapolitana annual harvest resulting from digging activity in Canal de Mira, Ria de Aveiro. Fish. Res. 76, 56-66.

De Juan S., Thrush S.F., Demestre M., 2007, Functional changes as indicators of trawling disturbance on a benthic community located in afishing ground (NW Mediterranean Sea). Mar. Ecol. Prog. Ser. 334, 117-129.

El Barhoumi M., Scaps P., Zghal F., 2013, Reproductive Cycle of Marphysa sanguinea (Montagu 1815) (Polychaeta: Eunicidae) in the Lagoon of Tunis. Sci. World J., ID 624197, 7 p.

Ellis J.I., Norkko A., Thrush S.F., 2000, Broad-scale disturbance of intertidal and shallow sublittoral soft-sediment habitats; effects on the benthic macrofauna. J. Aquat. Ecosyst. Stress Recovery. 7, 57-74.

Ferns P.N., Rostron D.M., Siman S.H.Y., 2000, Effects of mechanical cockle harvesting on intertidal communities. J. Appl. Ecol. 37, 464-474.

Frid C., 2003, Managing the health of the seafloor. Front. Ecol. Environ. 1, 429-436.

Gray J.S., 1997, Marine biodiversity: Patterns, threats and conservation needs. Biodiversity Conserv. 6, 153-175.

Gray J.S., Elliott M., 2009, Ecology of marine sediments, for science to Management, 2nd edition. Oxford University press.

Halpern B.S., Walbridge S., Selkoe K.A., Kappel C.V., Micheli F., D’Agrosa C., Bruno J.F., Casey K.S., Ebert C., Fox H.E., Fujita R., Heinemann D., Lenihan H.S., Madin E.M.P., Perry M.T., Selig E.R., Spalding M., Steneck R., Watson R., 2008. A global map of human impact on marine ecosystems. Science. 319, 948-952. 
Hamdi N., Charfi-Cheikhrouha F., Moali A., 2008, Le peuplement des oiseaux aquatiques hivernant du Golfe de Gabès (Tunisie). Bull. Soc. Zool. Fr. 133, 267-275.

Hamza F., Hammouda A., Selmi S., 2015, Species richness patterns of waterbirds wintering in the gulf of Gabès in relation to habitat and anthropogenic features. Estuarine Coastal Shelf Sci. 165, 254-260.

Henniger T.O., Forenamen P.W., 2011, Macrofaunal community structure in the littoral zone of a freshwater-deprived, permanently open Eastern Cape estuary. Afr. Zool. 46, 263-279.

Isenmann P., Gaultier T., El Hili A., Azafzaf H., Dlensi H., Smart, M., 2005, Oiseaux de Tunisie/Birds of Tunisia. Société d'Etudes Ornithologiques de France, Muséum Naturelle d'Histoire Naturelle, Paris, p. 432.

Jennings S., Pinnegar J., Polunin N., Warr K., 2001, Impacts of trawling disturbance on the trophic structure of benthic invertebrate communities. Mar. Ecol. Prog. Ser. 213, 127-142.

Kaiser M., Spencer B., 1994, Fish scavenging behaviour in recently trawled areas. Mar. Ecol. Prog. Ser. 112, 41-49.

Mosbahi N., Boudaya L., Dauvin J.C., Neifar L., 2015, Spatial distribution and abundance of the intertidal benthic macrofauna from the Kneiss islands (Gulf of Gabès, Tunisia). Cah. Biol. Mar. 56, 319-328.

Mosbahi N., Pezy J.P., Dauvin J.C., Neifar L., (submitted), Towards a management of the European clam harvesting around the Kneiss Islands (Gulf of Gabès, Tunisia). Cah. Biol. Mar.

Munari C., Balasso E., Rossi R., Mistri M., 2006, A comparison of the effects of different types of clam rakes on non-target, subtidal benthic fauna. Ital. J. Zool. 73, 75-82.

Navon M., Dauvin J.C., 2013, The immediate impact of intertidal pebble fork harvesting on the warty venus Venus verrucosa benthic community. Cah. Biol. Mar. 54, 385-392.

Olive P.J.W., 1993, Management of the exploitation of the lugworm Arenicola marina and the ragworm Nereis virens (Polychaeta) in conservation areas. Aquat. Conserv. 3, 1-24.
Rossi F., Forster R.M., Montserrat F., Ponti M., Terlizzi A., Ysebaert T., Middelburg J.J., 2007, Human trampling as short-term disturbance on intertidal mudflats: effects on macrofauna biodiversity and population dynamics of bivalves. Mar. Biol. 151, 2077-2090.

Sammari C., Koutitonsky V.G., Moussa M., 2006, Sea level variability and tidal resonance in the Gulf of Gabès, Tunisia. Cont. Shelf Res. 26, 338-350.

Seurat L.G., 1924, Observations sur les limites, les faciès et les associations de l'étage intercotidal de la petite Syrte (Golfe de Gabès). Bull. Sta. Océa. Salam, 72 p.

Snelgrove P.V.R., Blackburn T.H., Hutchings P.A., Alongi D.M., Grassle J.F., Hummel H., King G., Koike I., Lambshead P.J.D., Ramsing N.B., Solis-Weiss V., 1997, The importance of marine sediment biodiversity in ecosystem processes. AMBIO 26, 578-58.

Van Dijk A.J., Van Dijk K., Dijksen L.J., Van Spanje T.M., Wymenga E., 1986, Wintering Waders and Waterfowl in the Gulf of Gabès, Tunisia, January-march 1984, Report 11 of the Working Group on International Waderbird and Wetland Research. Working Group on International Waderbird and Wetland Research, Zeist.

Turpie I.K., Adams J.B., Joubert A., Harrison T.D., Colloty B.M., Maree R.C., Whitfield A.K., Wooldridge T.H., Lamberth S.J., Taljaard S., Van Niekerk L., 2002, Assessment of the conservation priority status of South African estuaries for use in management and water allocation. Water SA. 28, 191-206.

Watson G.J., Farrell P., Stanton S., Skidmore L.C., 2007, Effects of bait collection on Nereis virens populations and macrofaunal communities in the Solent, UK. J. Mar. Biol. Assoc. UK. 87, 703-716.

Wassenberg T., Dews G., Cook S., 2002, The impact of fish trawls on megabenthos (sponges) on the north-west shelf of Australia. Fish. Res. 58, 141-151.

http://www.ukmarinesac.org.uk/activities/bait-collection/bc18.htm 